\title{
The Trade in African Medicinal Plants in Matonge-Ixelles, Brussels (Belgium)
}

\author{
Tinde van Andel ${ }^{*} 1$ and Marie-Cakupewa C. Fundiko ${ }^{2}$ \\ ${ }^{1}$ Naturalis Biodiversity Center, Leiden, The Netherlands \\ ${ }^{2}$ Institute of Biology, Leiden University, Leiden, The Netherlands \\ *Corresponding author; e-mail: tinde.vanandel@naturalis.nl
}

Maintaining cultural identity and preference to treat cultural bound ailments with herbal medicine are motivations for migrants to continue using medicinal plants from their home country after moving to Europe and the USA. As it is generally easier to import exotic food than herbal medicine, migrants often shift to using species that double as food and medicine. This paper focuses on the trade in African medicinal plants in a Congolese neighborhood in Brussels (Belgium). What African medicinal plants are sold in Matonge, where do they come from, and to which extent are they food medicines? Does vendor ethnicity influence the diversity of the herbal medicine sold? We hypothesized that most medicinal plants, traders, and clients in Matonge were of Congolese origin, most plants used medicinally were mainly food crops and that culture-bound illnesses played a prominent role in medicinal plant use. We carried out a market survey in 2014 that involved an inventory of medicinal plants in 19 shops and interviews with 10 clients of African descent, voucher collection and data gathering on vernacular names and uses. We encountered 83 medicinal plant species, of which $71 \%$ was primarily used for food. The shredded leaves of Gnetum africanum Welw., Manihot esculenta Crantz, and Ipomoea batatas (L.) Lam were among the most frequently sold vegetables with medicinal uses. Cola nuts, shea butter, Aloe vera (L.) Burm.f., and Mondia whitei (Hook.f.). Skeels were the main non-food medicines sold. Women's health, aphrodisiacs, and rituals were the most important medicinal applications, but culture-bound ailments did not entirely dominate the plant uses. While most clients in Matonge were Congolese, most vendors and plant species were not. The Pakistanis dominated the food trade, and typical Congolese plants were sometimes replaced by West African species, creating confusion in vernacular names. African-managed shops had significantly more species of medicinal plants in stock than shops managed by Pakistanis. Almost all non-food herbal medicine was sold by Africans. Apart from informal shops, non-food herbal medicine was also sold from private homes and by ambulant vendors, probably to reduce costs and escape taxes and control by the authorities. We expect that in the future, increasing rent, strict regulations, and decreasing investments by the Congolese community will force the medicinal plant trade in Matonge to go even more underground.

Le commerce des plantes médicinales africaines à Matonge-lxelles, Bruxelles (Belgique). L'Ethnobotanique urbaine, en particulier l'étude des usages des plantes par les migrants en Europe et aux Etats Unis, est une science qui de développe très rapidement. Le souci de maintenir leur identité culturelle et la préférence de traiter des maladies dites de culture par les plantes médicinales, constituent les raisons qui motivent les migrants à continuer à recourir à la pharmacopée traditionnelles de leurs pays d'origine. Comme il est plus facile d'importer les aliments exotiques que les plantes médicinales, les migrants glissent souvent vers les espèces à 
double usage, à la fois alimentaire et médicinal. Le présent travail se concentre sur le commerce des plantes médicinales Africaines à Matonge-Ixelles, connu comme un quartier populaire Congolais à Bruxelles (Belgique). Quelles plantes médicinales Africaines sont vendues à Matonge, de quelle origine proviennent-elles? Dans quelle mesure ces plantes sont-elles à la fois alimentaires et médicinales? L'ethnicité des vendeurs influence-t-elle la diversité des herbes médicinales vendues? Notre hypothèse était que la plupart des plantes médicinales vendues, les vendeurs et les acheteurs à Matonge étaient d'origine Congolaise, et que les maladies dites de culture joueraient un rôle prépondérant dans l'usage des plantes médicinales vendues. Nous avons conduit des enquêtes sur le marché en 2014 comprenant l'inventaire des plantes médicinales dans 19 points de vente, des entretiens avec 10 clients d'origine Africaine, la collection des specimens, et des données sur les noms vernaculaires des plantes et leurs usages. Nos enquêtes du marché et les entretiens ont permis d'inventorier un total de 83 espèces de plantes médicinales, dont $71 \%$ étaient principalement utilisées comme aliments. Les feuilles râpées de Gnetum africanum Welw., Manihot esculenta Crantz et Ipomoea batatas (L.) Lam étaient les légumes les plus vendues comme médicament. Alors que les noix de cola, le beurre de karité, Aloe vera (L.) Burm.f. et Mondia whitei (Hook.f.) Skeels étaient les principales plantes médicinales non comestibles vendues. La santé des femmes, les aphrodisiaques et les plantes rituelles étaient les plantes médicinales les plus dominantes, alors que les affections dites de culture étaient faiblement représentées dans les usages des plantes. Malgré que la majorité des clients à Matonge soient d'origine Congolaise, la plupart des vendeurs des plantes venaient d'ailleurs. Les Pakistanais dominaient le commerce des aliments et les plantes typiquement Congolaises étaient des fois remplacées par des espèces Ouest Africaines, créant ainsi une confusion des noms vernaculaires. Les magasins gérés par les Africains représentaient plus de plantes médicinales en stock comparativement à ceux gérés par les Pakistanais, et presque toutes les plantes médicinale non comestibles étaient vendues par les Africains. L'inspection des points formels de vente n'a pas couvert l'entièreté de la diversité floristique à Matonge: les plantes médicinales non-comestibles étaient aussi vendues depuis des adresses privées, et par des vendeurs ambulants, probablement pour réduire les couts, les taxes exorbitantes, et le contrôle par les autorités. Nous espérons qu'à l'avenir, l'augmentation du loyer, une réglementation stricte et la diminution des investissements par la communauté Congolaise obligera le commerce des plantes médicinales à Matonge de disparaitre dans l'informel.

Key Words: African diaspora, Democratic Republic of Congo, Food medicine, Market survey, Medicinal plants, Urban ethnobotany..

\section{Introduction}

Urban ethnobotany, the study of plants used by people in urban environments, in particular among migrant communities, is a rapidly developing field (Ladio and Albuquerque 2016; Vandebroek and Balick 2012). Migrants commonly hold on to their cultural preference of food crops, dishes, and herbal medicines from their homeland, and often maintain traditional concepts on health and illness (Muniz de Medeiros et al. 2012; Pieroni and Vandebroek 2007). This can be seen as a strategy for strengthening their own identity in the host country, but the migrant's use of medicinal plants can also be motivated by a limited access to modern healthcare due to a lack of insurance or unemployment (Balick et al. 2000; Vandebroek et al. 2007). Culture- bound syndromes (e.g., the 'evil eye') are also preferably treated with herbal medicine, as biomedical providers in the host country often do not recognize these ailments (Bayles and Katerndahl 2009; Van Andel and Westers 2010). Migrants often face constraints on the availability of medicinal plant species formerly used in their home countries due to strict laws regarding the import and sale of medicinal plants (Ceuterick et al. 2011; Viladrich 2007; Vandebroek and Balick 2014). As a result, medicinal herbs sold on migrant markets are dominated by food medicines, plants with primarily culinary applications (e.g., fruits, vegetables, staple foods, or spices) that and serve a dual purpose as medicine (Pieroni et al. 2008; Vandebroek and Balick 2012). Moreover, food medicines are mostly widely known species and knowledge about them is more easily 
exchanged in the multicultural setting of large cities than less familiar, strictly medicinal plants that have a more restricted distribution (Vandebroek and Balick 2014).

Markets are public places, distinctive for each given culture or society, and they represent small-scale reproductions of that region's cultural and biological diversity (De Albuquerque et al. 2007). As a result, many exotic plant food and medicines can be found on multicultural urban markets. Recently, ethnobotanists have studied the medicinal plant trade and use by migrants in European urban areas, such as Turks in Germany (Pieroni et al. 2005), Thais in Sweden (Lundeberg 2007), Surinamers in the Netherlands (van Andel et al. 2007; van Andel and Westers 2010), Senegalese in Italy (Ellena et al. 2012), and Latinos (Ceuterick et al. 2011), Sikhs (Sandhu and Heinrich 2005) and Pakistanis in the UK (Pieroni et al. 2008). The present study focuses on the medicinal plant trade in the predominantly Congolese neighborhood Matonge-Ixelles in Brussels, Belgium. Originally, the name of a famous center for business, music, and nightlife in Kinshasa, the capital of the Democratic Republic of Congo (former Zaire), the Belgian Matonge represents an international meeting place for African migrants in Brussels. Although Belgium did inherit a trusteeship over Rwanda and Burundi after World War II, Congo was Belgium's only colony until its independence in 1960. The violent civil war and the general collapse of state control in the Democratic Republic of the Congo (DRC) in the 1990s caused a massive migration of Congolese refugees, of which ca. 70,000 are now estimated to live in Belgium, where they form the largest group of Sub-Saharan immigrants (Demart 2013a; Swyngedouw and Swyngedouw 2009). In the 1970s, after the opening of the Congolese student hostel La Maison Africaine, followed by a nightclub, food shops, and galleries around the Chaussé de Wavre, this Ixelles neighborhood received the names Le Petit Congo and Le Petit Matonge de Bruxelles. Nowadays, Matonge is known as a vibrant, multicultural meeting place for migrants, tourists, businesspeople, and young Belgians that come to shop, eat, and party in the numerous African hair and beauty salons, wax print fabric shops, exotic groceries, restaurants, and music bars (Beddington 2013). On the other hand, Matonge has the reputation as being unsafe. After several street riots in 2001 and in the winter of 2011-2012, problems with drug dealers and gang fights, the neighborhood remains under intensified police control (Demart 2008, 2013b). Apart from an overview of non-timber forest products sold on the French and Belgian markets (Tabuna 1999), no studies in urban ethnobotany exist for the African diaspora in Belgium. In this paper, we addressed the following questions: (1) What African medicinal plants are sold in Matonge and for which diseases are they used? (2) To which extent can these plants be characterized as food medicines? (3) Which ethnicities are involved in the trade of African medicinal plants in Matonge? (4) Does vendor ethnicity influence the floristic diversity of the herbal medicine sold?

We assumed the herbal medicines, traders, and clients in Matonge to be predominantly of Congolese origin. We further hypothesized that Congolese migrants in Matonge would mainly buy medicinal plants to treat culture-bound illnesses for which no synthetic treatment is available in Belgium. Finally, because it is easier to import and sell food plants in Europe than herbal medicine, we expected that most medicinal plants sold in Matonge fall within the category food medicines.

\section{Methods}

A market survey was carried out in the neighborhood of Matonge-Ixelles, near the Metro station Porte de Namur on the eastern fringe of Brussels city center, on several days between March and June 2014. We counted the number of shops and market stalls that sold African medicinal plants in the area around the Chaussé de Wavre (French) or Waversesteenweg (Dutch), Matonge's main commercial street located around $50^{\circ} 49^{\prime} 17^{\prime \prime} \mathrm{N}, 4^{\circ} 24^{\prime}$ 24" E (Fig. 1). We entered shops selling African food and inventoried whether they were selling medicinal plant products and vegetables that doubled as medicine. We counted the number of medicinal plant species per shop. The proportion of food- and non-food medicine was calculated afterwards. We obtained information on vernacular names, preparation methods, and medicinal and food uses from both shopkeepers and clients.

Short semi-structured interviews held with several shopkeepers included questions on their ethnicity, species of medicinal plants sold, type of clients, and provenances of the plant product sold. Questionnaires were held by the second author in English, French, or in the Congolese languages Lingala and Swahili, according to the preferred language of the participant. Additional semi-structured interviews were held among ten African migrants who regularly bought herbal medicine at 


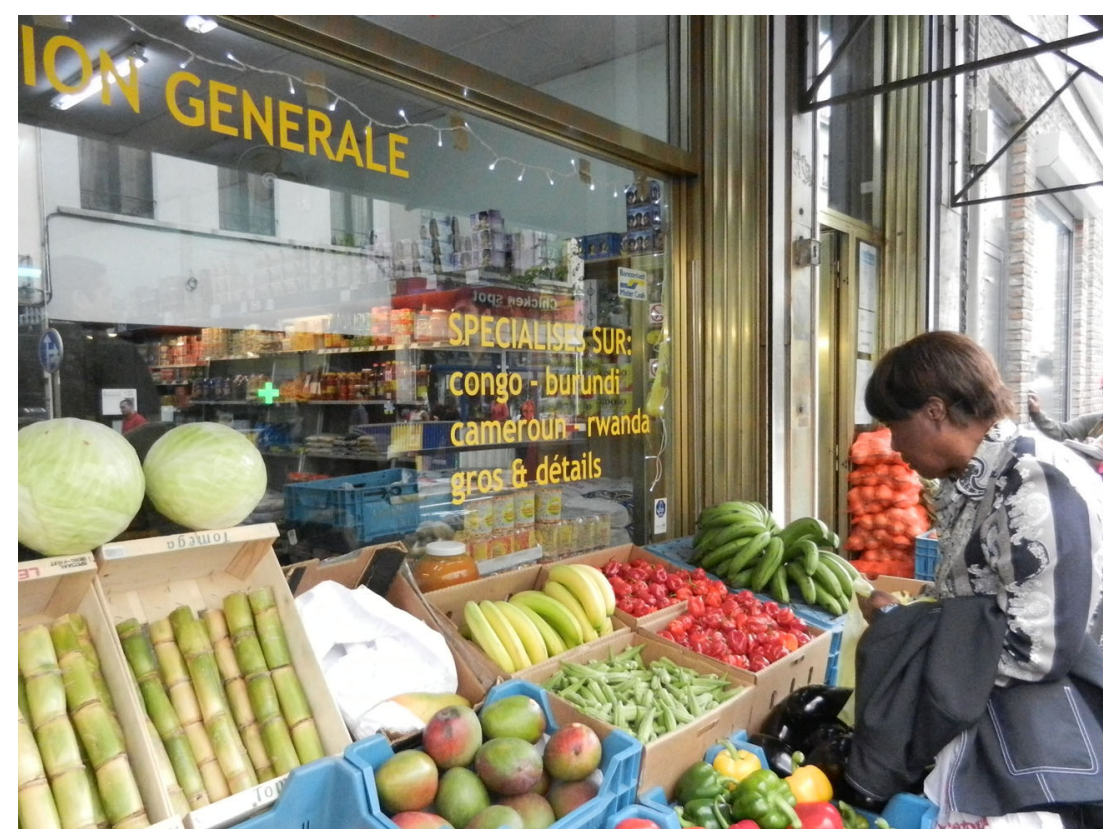

Fig. 1. African food shops along the main commercial street at Matonge. Picture by M.C.C. Fundiko.

Matonge. We asked them to name the (vernacular) names of the species they bought, their motivation to buy medicinal plants, how they purchased the herbal medicine (from shops or via the informal circuit), and for which ailments they used these plants. Prior informed consent was obtained from all plant vendors and consumers before the interviews and the collection of data on plant names and uses.

Plant specimens that could not be identified on the spot were purchased, processed into botanical vouchers, identified, and deposited at the herbarium of Naturalis Biodiversity Center (L) at Leiden, the Netherlands. Scientific names were checked with the Plant List (www.theplantlist.org). When vernacular plants names were mentioned during interviews but the particular species was not available in the shops, or when specimens lacked sufficient morphological features for identification, we verified their vernacular names with literature (e.g., Daeleman and Pauwels 1983; Schmelzer and Gurib-Fakim 2008, 2013; Tabuna, 1999; Termote et al. 2012) and online databases, such as the PROTA Database (www.prota4u.org) and the Prelude Medicinal plant database (www.africamuseum. be/collections/external/prelude). To compare the floristic diversity of medicinal plants in shops managed by Africans with shops managed by non-Africans, we first used a Kolmogorov-Smirnov test to see whether our data were normally distributed. When this was the case, we compared the mean number of plant species sold by African and nonAfricans by means of a one-sample $t$ test. All statistical tests were done in the program SPSS 19.

\section{Results}

\section{Traded Species}

In the 19 shops in Matonge that sold African plants, we recorded ca. 69 species and collected 54 specimens, of which one wood/bark specimen remained unidentified and six species could only be identified to genus level (Electronic Supplementary Material (ESM), Appendix 1). We conducted ten interviews with African clients that regularly bought herbal medicine in Matonge (four males, six females, 20-65 years old, migrants from the DRC, Burundi, Burkina Faso, Senegal, Mauritania, and Cameroon, living in Belgium, France, and the Netherlands). During those interviews, an additional 14 plant species were mentioned to have been bought in Brussels, but were not available in the shops at the time of our fieldwork; two of which were of sufficient quality to make botanical vouchers. All plant species are listed with their 
TABLE 1. THE TOP 15 OF MOST FREQUENTLY SOLD PLANT SPECIES USED AS FOOD MEDICINE IN 19 SHOPS IN MATONGE, BRUSSELS (MARCH-JUNE 2014).

\begin{tabular}{|c|c|c|}
\hline Species & $\begin{array}{l}\text { Plant part } \\
\end{array}$ & $\overline{\text { Percentage }}$ \\
\hline Gnetum africanum & $\begin{array}{l}\text { Sliced leaves } \\
\quad \text { (frozen or dried) }\end{array}$ & $89 \%$ \\
\hline Elaeis guineensis & Oil from fruits & $84 \%$ \\
\hline Colocasia esculenta & Starchy tuber & $84 \%$ \\
\hline Capsicum anпuит & Fresh and dried fruits & $79 \%$ \\
\hline Manihot esculenta & $\begin{array}{l}\text { Starchy tuber } \\
\text { and frozen leaves }\end{array}$ & $79 \%$ \\
\hline $\begin{array}{c}\text { Abelmoschus } \\
\text { esculentus }\end{array}$ & Fresh fruits & $79 \%$ \\
\hline Ipomoea batatas & Fresh leaves & $74 \%$ \\
\hline Musa $\times$ paradisiaca & Fresh fruits & $68 \%$ \\
\hline Hibiscus acetosella & $\begin{array}{l}\text { Fresh and } \\
\text { dried leaves }\end{array}$ & $32 \%$ \\
\hline Hibiscus sabdariffa & $\begin{array}{l}\text { Fresh leaves, } \\
\text { dried calyces }\end{array}$ & $26 \%$ \\
\hline Aloe vera & Fresh leaves & $26 \%$ \\
\hline Zingiber officinale & Fresh rhizomes & $26 \%$ \\
\hline Dacryodes edulis & Fresh fruits & $21 \%$ \\
\hline Cola nitida* & Fresh seeds & $21 \%$ \\
\hline Garcinia kola* & Fresh seeds & $21 \%$ \\
\hline
\end{tabular}

*Species not primarily sold as food

family, scientific and vernacular name, voucher numbers, plant parts, and food and medicinal uses in ESM.

The most species-rich families were the Leguminosae (nine spp.), followed by the Malvaceae (eight spp.), Apocynaceae (five spp.), and Solanaceae (five spp., Solanum aethiopicum L. with two different cultivars). The Leguminosae is a very large family and thus contains many medicinal species, but the less diverse families of Apocynaceae, Solanaceae, and Malvaceae contain a disproportionally high percentage of species with therapeutic value (Moerman 1991). In total, ca. 83 plant species were either encountered in the shops or were said to have been bought there, of which 57 (71\%) were used both for food and medicine. Table 1 lists the 15 most frequently sold plant species in Matonge, calculated as the percentage of shops in which we encountered the species. Apart from the seeds of Cola nitida (Vent.), Schott and Endl. (cola nut) and Garcinia kola Heckel (bitter cola nut), which are chewed as stimulants and aphrodisiacs, all these frequently sold species are used primarily as food.

Typically, the fresh, sour fruits of the rainforest liana Landolphia owariensis P. Beauv. (Apocynaceae) were also offered for sale (Fig. 2). They are known among the Congolese as 'Matonge' in Lingala, and it was after these fruits that the Kinshasa nightlife quarter (and eventually the Brussels neighborhood) was originally named. The fruits are said to be very healthy and should be eaten by people suffering from bronchitis.

We observed that the somewhat similar-looking and tasting fruits of the West African savanna liana Saba senegalensis (A. DC.). Pichon were also marketed as 'Matonge' in two shops, although this species does not occur in Congo and was probably

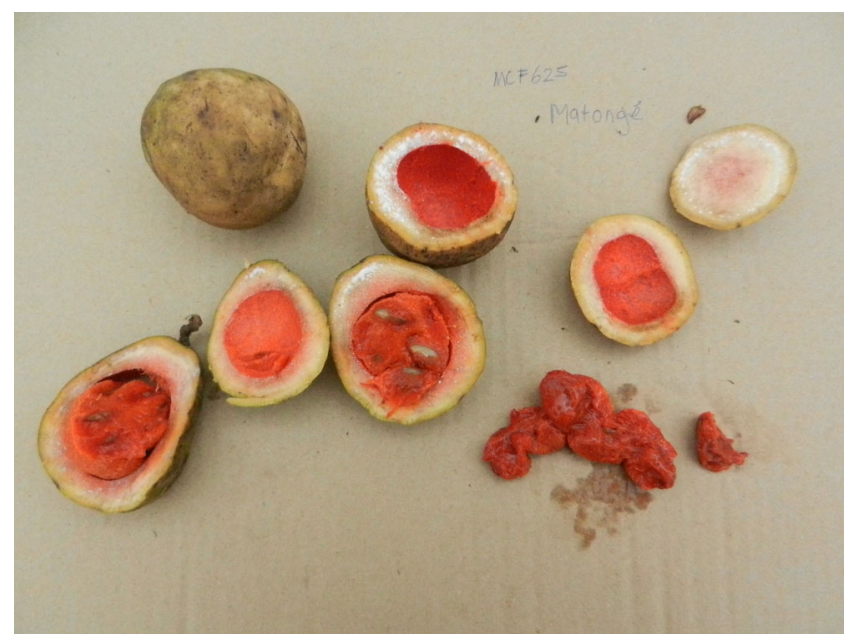

Fig. 2. Fresh Matonge fruits (Landolphia owariensis), a popular, wild-harvested fruit in the DRC. Picture by M.C.C. Fundiko. 


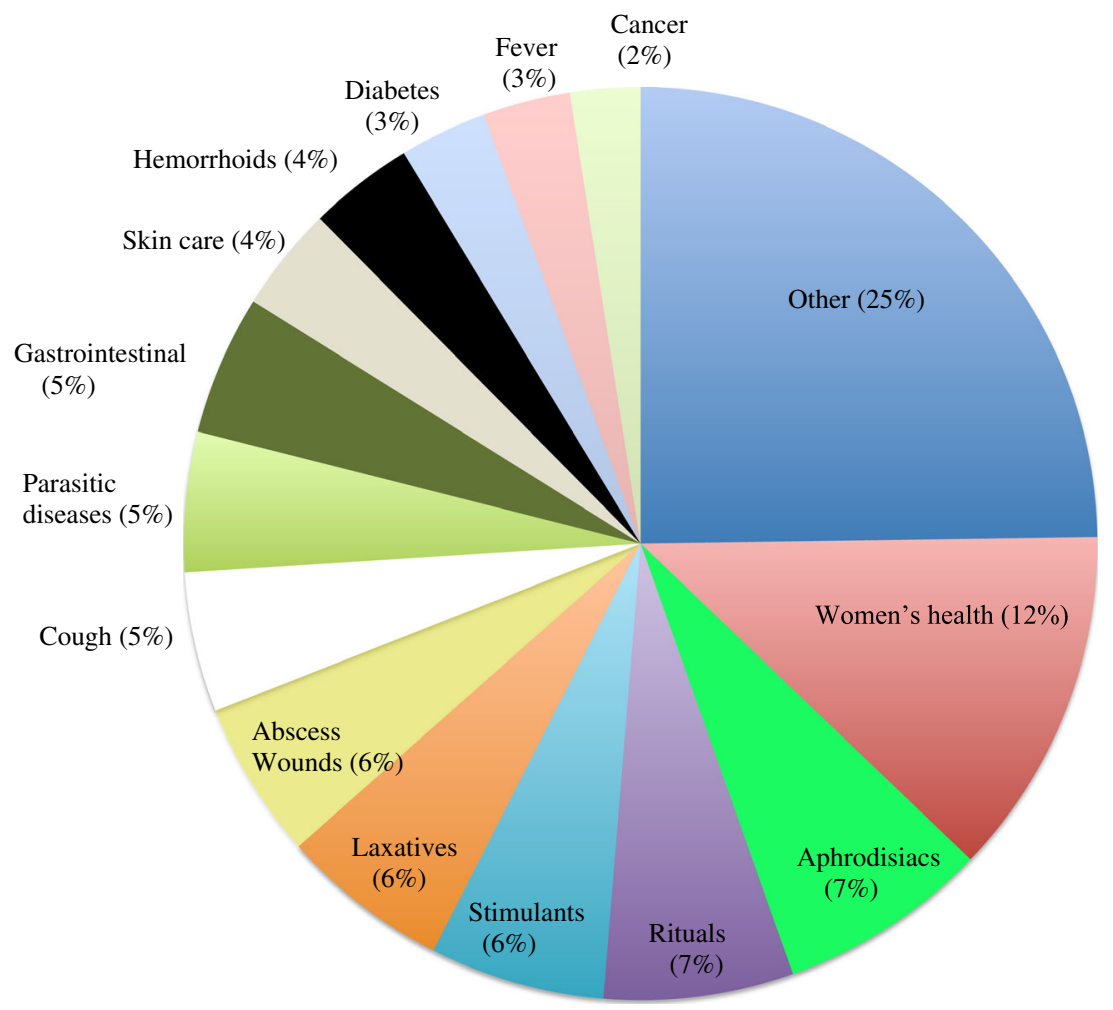

Fig. 3. Most frequently mentioned disease categories, expressed as percentage of the total number of plant species.

imported from Mali. Some Congolese, however, recognized the Saba fruits as different from Landolphia and called them 'Makalakonki' (Kikongo), a name used in the DRC for the edible fruits of Strychnos spp. that have a similar color and size.

\section{Medicinal Applications}

Clients and shopkeepers mentioned a total of 162 medicinal uses for a wide variety of ailments, of which the most frequent are visualized in Fig. 3. Women's health was a major category: plants were used to ensure a healthy pregnancy, ease birth, treat postpartum hemorrhage, and induce abortion. Twelve species were mentioned as aphrodisiacs for men, several of which were also used as general stimulants. Although diabetes seemed a minor category with only five plant species listed for treatment, two of these species were among the top three of the most frequently sold food medicines. The same accounts for hypertension, treated by the lemonade made from Hibiscus sabdariffa L., of which the calyces were sold in more than $25 \%$ of the shops and by onions, commonly available in supermarkets throughout the country (ESM).

Rituals also played a role in the trade in African plants: the fragrant bark of Commiphora sp. and the perfumed rhizomes of Cyperus esculentus L. were burnt inside the house to chase away bad spirits. The fresh leaves of Ocimum gratissimum L. served as essential ingredients in the ritual dish Tschilwabenye, cooked with chicken and palm oil and served to the in-laws of the young bride during marriage ceremonies of the Congolese Baluba ethnic group. One client lamented the recent death of a Congolese traditional healer, active in Matonge and Clemenceau, a nearby Brussels neighborhood, who was a specialist in the Beta Zeke ritual, which includes throwing shells to predict people's future and their luck in travel, health, and employment.

\section{Provenance of Plants}

The interviews with vendors and clients revealed that the origin of the plants sold at Matonge was more diverse that previously anticipated. Each vendor had 
his or her own providers and network. Apart from the DRC, the most cited countries of origin of the plant material were Cameroon, Ghana, Senegal, Benin, Mali, South Africa, and Uganda. Some herbal medicine and food plants bought by African customers were also imported from Brazil, Colombia, or Thailand. When we compared our species list with the literature on medicinal plants used in the DRC, we found nine species that did not occur in the DRC, but were typical medicinal plants of the West African dry zones (Arbonnier 2004): Acacia nilotica (L.) Delile, Annickia polycarpa (DC.) Setten and Maas ex I.M.Turner, Commiphora sp., Cyperus esculentus, Saba senegalensis and Ziziphus mucronata Wildd., Combretum micranthum G.Don, and Combretum sp. The latter two species were marketed as the medicinal tea Kenkeliba. All these species carried Pulaar and/or Wolof names, and were probably imported from Senegal or Mali, just like the unidentified bark sample MCCF653, known as Dadi (Pulaar) and boiled as tea against stomachache. The clients that we interviewed did not buy all their medicinal plants at the African shops in Matonge. They also ordered plants directly by air parcels from their family and friends in Africa, from Congolese migrants in Brussels who sold their herbal medicine from their private garages or even delivered at the client's home, and from ambulant vendors who were said to walk into restaurants, barbershops, and African beauty salons in Matonge with bags of medicinal plants. According to our respondents, these ambulant vendors sold specific types of African herbal medicine (e.g., strong aphrodisiacs) that were difficult to find in the official food shops. This informal trade system probably explains the discrepancy in species mentioned during interviews and observed in shops.

\section{Vendor Ethnicity and Diversity in Herbal MEDICINE}

Just six of the 19 shops selling African food medicine were managed by African migrants (one Mauritanian, one Senegalese, two Cameroonians, and three Congolese). The remaining 13 shops (68\%) were all managed by Pakistanis. After proving that our data were normally distributed, the one-sampled $t$ test showed that the shops managed by Africans had a significant higher number of medicinal plant species in stock (an average of ca. 20 species) than those managed by Pakistanis, who sold an average of ca. 11 species $(t=6.623, p=$ $0.000)$. Besides the two species Garcinia kola and
Cola acuminata, 24 of the 26 (92\%) of non-food herbal medicines were encountered in Africanmanaged sale points.

In general, the Pakistani shopkeepers were very reluctant to answering questions and often said they did not know any medicinal applications for their plant products. The African vendors, however, were also uncomfortable in providing plant use information. A Mauritanian shopkeeper, who sold a variety of West African medicines, explained his hesitance as follows: "There are difficulties that we encounter during the provision and the trade in plant products." A Congolese vendor said she "could not give any interview due to security problems." Another shopkeeper from the DRC, who had lived in Matonge for 40 years, said that Congolese migrants were nowadays less interested in the trade in food or medicine due to high taxes, unaffordable rent and "the regulations." A Congolese customer argued that the tense police control in the neighborhood and the negative impact of the migrants' activities had led to the closing of several Matonge selling points by the authorities.

\section{Motivations to Buy African Traditional Medicine at Matonge}

Regardless of the problems faced by the vendors while running their businesses and the apparent need to keep their commercial network secret from the authorities, Congolese migrants, also those living in France or the Netherlands, still constitute the most important group of customers at Matonge. The shops managed by Africans also served as multicultural meeting places, where knowledge on traditions and herbal medicine was still being shared among vendors and clients. Customers said they bought food and medicine at Matonge to strengthen their cultural identity and wanted to encourage African vendors to spread their traditions and culture in Europe. Several clients said that traditional medicines were more effective than modern medicine, such as ground pumpkin seeds (Cucurbita pepo L., of the Mbika cultivar), consumed to treat prostate cancer. Some illnesses were said to be "typically African" and "ignored by European physicians." An example was the Congolese cultural bound illness Mpese, a severe type of eczema and skin infection that was "caused by enemies who throw the sickness on someone" and "usually very difficult to be treated by synthetic medicine." Finally, a Congolese woman living in the Netherlands said she preferred medicinal plants above pills, since "the herbal medicine from my country does not 
contain harmful elements such as pesticides, because these plants are collected in the forest."

\section{Discussion and Conclusions}

Matonge offers a variety of medicinal plant species to its African customers, but the sale in herbal medicine remains somewhat hidden. While food medicines are openly offered for sale, non-food medicines are sold almost exclusively by African-managed shops, which keep them under the counter or conceal them wrapped in newspaper, by ambulant vendors and illegal shops in private homes or garage boxes. For several reasons, our market survey has only uncovered part of the entire diversity of African traditional medicine sold in this multicultural neighborhood. Powdered and fragmented medicinal plant products, herbal extracts, dried caterpillars, and edible fungi sold at Matonge were excluded because of identification problems. Moreover, due to the informal (and largely invisible) trade and the general reluctance of providing medicinal uses for plants, we must have missed several species of herbal medicine sold "under the counter."

Culture-bound illnesses certainly played a role in the demand for herbal medicine in Matonge. The popularity of aphrodisiac plants is also known from West African (Quiroz et al. 2014; Van Andel et al. 2012) and Central African markets (Biloso and Lejoly 2006; Termote et al. 2012a; Towns et al. 2014) and the Afro-Caribbean (Van Andel et al. 2012b), where these bitter tonics are regarded as a part of one's manliness and cultural identity rather than just as treatments for impotence.

The category "women's health" also represented several cultural bound health beliefs often recorded among Africans and their diaspora, such as the use of herbs for vaginal baths (Van Andel et al. 2008) and specific food to ensure a healthy pregnancy (Towns and Van Andel 2016). Some of the plants marketed at Matonge could cause serious health risks, like the highly poisonous Erythrophleum africanum (Benth.) Harms (Kawanga 2006). The powdered bark of this tree is macerated with red earth and palm oil (Elaeis guineensis Jacq.) and rubbed on the body of nursing mothers who have just delivered in order to rejuvenate their skin.

Chronic diseases like diabetes and hypertension are increasingly prevalent among Sub-Saharan Africans and their diaspora, and caused by a change in lifestyle (different diet and less physical exercise) after migration from rural to urban areas (Beune et al. 2006; Mbanya et al. 1998, 2010; Vandebroek and Balick 2014). These illnesses were not that visible in our market survey with regard to the number of species used and the specific applications mentioned by our informants. We suggest, however, that future studies should focus on the potential of popular bitter African vegetables (e.g., Gnetum africanum Welw., Solanum spp., Momordia charantia L., and Vernonia amygdalina Delile) for diabetes prevention among migrants, as some of these have proven anti-diabetic effects (Atangwho et al. 2014; Van Andel and Carvalheiro 2013). The same accounts for vegetables consumed to lower hypertension, such as the two species mentioned by our informants (onions and Hibiscus sabdariffa), which both show activity against high blood pressure (Gbolade 2012; Walton et al. 2016). Although not relevant for the Belgian health situation, plant uses to combat tropical diseases such as malaria and intestinal parasites were still mentioned during our interviews, probably because they remain relevant for migrants frequently visiting their homeland.

While most of the customers in Matonge are migrants from the DRC, the traders and the herbal medicine itself are not necessarily Congolese. Traders can therefore not always meet the demand for specific Central African plants, which results in the substitution of highly valued Congolese plants by similarlooking West African species and a subsequent mixup in local names, as was illustrated by the replacement of the original Matonge fruit (Landolphia owariensis) by Saba senegalensis. Substitution of useful plants from the home country by "new" species in the host country is a common aspect of migrant ethnobotany (Muniz de Medeiros et al. 2012), as is the associated confusing mixture of retention, change and replacement of local names (Otieno et al. 2015; Van Andel et al. 2014).

When we compared our results with studies on Congolese medicinal plant use (Biloso and Lejoly 2006; Fundiko 1997; Katemo et al. 2012; Makumbelo et al. 2008; Mpiana et al. 2007; Tabuna 1999; Termote et al. 2012; www.prota4u), we found that $80 \%$ of the species we encountered in Matonge are also used as medicinal plants in Congo, while the remaining 20\% are typical West African species. However, several of the most commonly sold non-food medicinal plants in Kisangani (Katemo et al. 2012) and Kinshasa (Makumbelo et al. 2008), two major cities in the DRC, were not found in Matonge, such as Alchornea cordifolia (Schumach. and Thonn.) Müll.Arg., Annona senegalensis Pers., Bridelia ferruginea Benth., 
Hymenocardia acida Tul., and Newbouldia laevis (P.Beauv.) Seem. These species probably find their way to Belgium through the informal circuits.

The dominance of food medicine over non-food medicinal plants in Matonge is not simply explained by the fact that food plants are easier to sell and more widely known than herbal medicine or that it responds to a specific demand of the customers (Ceuterick et al. 2011; Vandebroek and Balick 2012, 2014; Viladrich 2007). The percentage of food-medicine species in the African neighborhood Matonge (71\%) was higher than the percentages reported among Dominicans in New York (>50\%) (Vandebroek and Balick 2014) and among Colombians $(70 \%)$, Peruvians $(62 \%)$, and Bolivians (57\%) in London (Ceuterick et al. 2011). The high percentage of food medicines in the African groceries in Brussels also appears a result of regulations inhibiting the marketing of medicinal plants in Belgium and the gradual take over by groceries managed by non-Africans. Although some of these Pakistani shop owners were actually born in the DRC (Swyngedouw and Swyngedouw 2009), their knowledge of (or motivation to engage in) non-food African herbal medicine seems limited. They apparently have better access to international trade networks, investment funds, official permits, and qualifications and/or are more willing to engage in obtaining these than native Congolese (Demart 2013b; Hubo 2015; Vandecandelaere 2012). Moreover, the Pakistani traders probably profited from the closure of several Congolese shops after the riots in 2001 and 2012 (Demart 2008; 2013b).

Shortly after the 1970s, African migrants could no longer afford to live in Matonge (Beddington 2013). With the diplomatic quarter of Brussels nearby, it is likely that rents will only go up in the future, and the now dilapidated apartments in Matonge become attractive for real estate investors to renovate and sell to affluent citizens (Vandecandelaere 2012). Therefore, we expect that although the commercialization in African food medicine will probably go on for some time (or move to a peripheral and cheaper neighborhood), the trade in non-food medicinal plants will go entirely underground. African migrants will continue to sell traditional medicine imported from their home country, but increasingly via the internet, out of view from the general public, taxes, quality and safety control entities, and researchers. The diversity of African herbal medicine and the exchange of ethnobotanical information, now provided by the African-managed shops, will become less accessible to migrants. It remains to be seen for how long Matonge will continue to be a "meeting at home place" for African migrants.

\section{Acknowledgments}

This research was funded by the Naturalis Biodiversity Center, Leiden University and the Alberta Mennega Foundation. We are grateful to botanist Jan Wieringa for identifying some of our specimens. Our special thanks go to all our shopkeepers and their customers in Matonge who participated in this survey.

Open Access This article is distributed under the terms of the Creative Commons Attribution 4.0 International License (http://creativecommons.org/ licenses/by/4.0/), which permits unrestricted use, distribution, and reproduction in any medium, provided you give appropriate credit to the original author(s) and the source, provide a link to the Creative Commons license, and indicate if changes were made.

\section{Literature Cited}

Albuquerque, U. P., J. M. Monteiro, A. M. Ramosa, and E. L. C. Amorim. 2007. Medicinal and magic plants from a public market in northeastern Brazil. Journal of Pharmacology 110(1):76-91.

Arbonnier, M. 2004. Trees, shrubs and lianas of West African dry zones. CIRAD, Montpellier.

Atangwho, I. J., K. B. Yin, M. I. Umar, M. Ahmad, and M. Z. Asmawi. 2014. Vernonia amygdalina simultaneously suppresses gluconeogenesis and potentiates glucose oxidation via the pentose phosphate pathway in streptozotocin-induced diabetic rats. BMC Complementary and Alternative Medicine 14(1):1.

Balick, M. J., F. Kronenberg, A. L. Ososki, M. Reiff, A. Fugh-Berman, B. O'Connor, M. Roble, P. Lohr, and D. Atha. 2000. Medicinal plants used by Latino healers for women's health conditions in New York City. Economic Botany 53(3):344-357.

Bayles, B. P. and D. A. Katerndahl. 2009. Culturebound syndromes in Hispanic primary care patients. International Journal of Psychiatry in Medicine 39(1):15-31.

Beddington, E. 2013. Out of Africa: Brussels' vibrant Matonge quarter. The Guardian (3 November 2013). Retrieved from https://www. theguardian.com/travel/2013/nov/03/brusselsmatonge-quarter-belgium (26 August 2016).

Beune, E. J., J. A. Haafkens, J. S. Schuster, and P. J. Bindels. 2006. "Under pressure": How 
Ghanaian, African-Surinamese and Dutch patients explain hypertension. Journal of Human Hypertension 20(12):946-955.

Biloso, A. and J. Lejoly. 2006. Etude de l'exploitation et du marché des produits forestiers non ligneux à Kinshasa. Tropicultura 24(3):183-188.

Ceuterick, M., I. Vandebroek, and A. Pieroni. 2011. Resilience of Andean urban ethnobotanies: A comparison of medicinal plant use among Bolivian and Peruvian migrants in the United Kingdom and in their countries of origin. Journal of Ethnopharmacology 136(1):27-54.

Demart, S. 2013a. Congolese migration to Belgium and postcolonial perspectives. African Diaspora 6(1):1-20.

2013b. Riots in Matonge and... the indifference of public authority? Brussels Studies 68: $1-8$.

- _ 2008. De la distinction au stigmate Matonge Un quartier congolais à Bruxelles. Cahiers La Fonderie 38:55-62.

Ellena, R., Quave, C.L. and Pieroni, A. 2012. Comparative medical ethnobotany of the Senegalese community living in Turin (Northwestern Italy) and in Adeane (Southern Senegal). Evidence-Based Complementary and Alternative Medicine Article ID 604363.

Fundiko, M.C.C. 1997. Phytothérapie de quelques maladies infectieuses et parasitaires à Kinshasa ( $\mathrm{Za}$ ïre). Mémoire, IPN, Dept. Biologie, Kinshasa.

Gbolade, A. 2012. Ethnobotanical study of plants used in treating hypertension in Edo State of Nigeria. Journal of Ethnopharmacology 144(1):1-10.

Hubo, B. 2015. Zonder Afrikaanse handelaars is Matonge zinloos. Brussels: Brussel Deze Week 12 May 2005. Retrieved from http://www. bruzz.be/nl/nieuws/zonder-afrikaansehandelaars-matonge-zinloos (26 August 2016)

Katemo, M., P. T. Mpiana, B. M. Mbala, S. O. Mihigo, K. N. Ngbolua, D. S. T. Tshibangu, and P. R. Koyange. 2012. Ethnopharmacological survey of plants used against diabetes in Kisangani city (DR Congo). Journal of Ethnopharmacology 144(1):39-43.

Kawanga, V. 2006. Erythrophleum africanum (Welw. ex Benth.) Harms. Plant Resources of Tropical Africa. Retrieved from www.prota4u.org (26 August 2016).

Ladio, A. H. and U. P. Albuquerque. 2016. Urban Ethnobiology. Pages 33-38 in U. P. De Albuquerque and R. R. Nóbrega Alves, eds., Introduction to Ethnobiology. Springer, New York.
Lundeberg, P. 2007. Use of traditional herbal remedies by Thai immigrant women in Sweden. Pages 104-121 in I. Vandebroek and A. Pieroni, eds., Traveling Cultures and Plants: The Ethnobiology and Ethnopharmacy of Human Migrations. Berghahn Publishers, New York.

Makumbelo, E., L. Lukoki, J. J. S. J. Paulus, and N. Luyindula. 2008. Stratégie de valorisation des espèces ressources des produits non ligneux de la savane des environs de Kinshasa: II. Enquête ethnobotanique (aspects médicinaux). Tropicultura 26(3):129-134.

Mbanya, J. C. N., E. M. Minkoulou, J. N. Salah, and B. Balkau. 1998. The prevalence of hypertension in rural and urban Cameroon. International Journal of Epidemiology 27(2):181-185.

- A. A. Motala, E. Sobngwi, F. K. Assah, and S. T. Enoru. 2010. Diabetes in Sub-Saharan Africa. The Lancet 375(9733):2254-2266.

Moerman, D. E. 1991. The medicinal flora of native North America: An analysis. Journal of Ethnopharmacology 31(1):1-42.

Mpiana, P. T., D. S. T. Tshibangu, O. M. Shetonde, and K. N. Ngbolua. 2007. In vitro antidrepanocytary actvity (anti-sickle cell anemia) of some Congolese plants. Phytomedecine 14(2): 192-195.

Muniz de Medeiros, P., Taboada Soldati, G., Leal Alencar, N., Vandebroek, I., Pieroni, A., Hanazaki, N. and Albuquerque, U.P. 2012. The use of medicinal plants by migrant people: Adaptation, maintenance, and replacement. Evidence-Based Complementary and Alternative Medicine, Article ID:807452

Otieno, J., S. Abihudi, S. Veldman, M. Nahashon, T. R. Van Andel, and H. J. De Boer. 2015. Vernacular dominance in folk taxonomy: a case study of ethnospecies in medicinal plant trade in Tanzania. Journal of Ethnobiology and Ethnomedicine 11(1):1-7.

Pieroni, A., H. Muenz, M. Akbulut, K. H. C. Başer, and C. Durmuşkahya. 2005. Traditional phytotherapy and trans-cultural pharmacy among Turkish migrants living in Cologne, Germany. Journal of Ethnopharmacology 102(1):69-88. , Q. Z. Sheikh, W. Ali, and B. Torry. 2008. Traditional medicines used by Pakistani migrants from Mirpur living in Bradford, Northern England. Complementary Therapies in Medicine 16(2):81-86.

_ and I. Vandebroek, eds. 2007. Travelling cultures and plants: The Ethnobiology and 
Ethnopharmacy of Human Migrations. Berghahn Publishers, New York.

Quiroz, D., A. M. Towns, S. I. Legba, J. Swier, S. Brière, M. S. M. Sosef, and T. R. Van Andel. 2014. Quantifying the domestic market in herbal medicine in Benin, West Africa. Journal of Ethnopharmacology 151(3):1100-1108.

Sandhu, D. S. and M. Heinrich. 2005. The use of health foods, spices and other botanicals in the Sikh community in London. Phytherapy Research 19(7):633-642.

Swyngedouw, E. and E. Swyngedouw. 2009. The Congolese diaspora in Brussels and hybrid identity formation: Multi-scalarity and diasporic citizenship. Urban Research and Practice 2(1):68-90.

Tabuna, H. 1999. Le marché des produits forestiers non ligneux de l'Afrique Centrale en France et en Belgique: produits, acteurs, circuits de distribution et débouchés actuels. CIFOR Occasional Paper 19, Bogor.

Termote, C., G. Everaer, M. B. Meyi, B. D. Djailo, and P. Van Damme. 2012. Wild edible plant markets in Kisangani, Democratic Republic of Congo. Human Ecology 40(2):269-285.

Towns, A. M., D. Quiroz, L. Guinee, H. J. de Boer, and T. R. Van Andel. 2014. Volume, value and floristic diversity of Gabon s medicinal plant markets. Journal of Ethnopharmacology 155(2):1184-1193.

_ and T. R. Van Andel. 2016. Wild plants, pregnancy, and the food-medicine continuum in the southern regions of Ghana and Benin. Journal of Ethnopharmacology 179(3):375-382.

Van Andel, T. R., B. Myren, and S. Van Onselen. 2012a. Ghana's herbal market. Journal of Ethnopharmacology 140(2):368-378.

—, S. De Korte, D. Koopmans, J. A. BehariRamdas, and S. Ruysschaert. 2008. Dry sex in Suriname. Journal of Ethnopharmacology 116(1):84-88.

Van Andel, T.R. and Carvalheiro, L.G. 2013. Why urban citizens in developing countries use traditional medicines: the case of Suriname. Evidence Based. Complementary and Alternative Medicine 2013, Article ID:687197.

Van Andel, T. R., S. Mitchell, G. Volpato, I. Vandebroek, J. Swier, S. Ruysschaert, C. A. Rentería Jiménez, and N. Raes. 2012b. In search of the perfect aphrodisiac: Parallel use of bitter tonics in West Africa and the Caribbean. Journal of Ethnopharmacology 143(3):840-850.

Van Andel, T.R., van't Klooster, C.I.E.A., Quiroz, D., Towns, A.M., Ruysschaert, S. and Van den Berg, M. 2014. Local plant names reveal that enslaved Africans recognized substantial parts of the New World flora. PNAS 111:E5346-E5353.

Van Andel, T. R. and C. I. E. A. Van't Klooster. 2007. Medicinal plant use by Surinamese immigrants in Amsterdam, the Netherlands. Pages 122-144 in A. Pieroni and I. Vandebroek, eds., Traveling cultures and plants: The Ethnobiology and Ethnopharmacy of Human Migrations. Berghahn Publishers, New York.

- and P. Westers. 2010. Why Surinamese migrants in the Netherlands continue to use medicinal herbs from their home country. Journal of Ethnopharmacology 127(3):694-701.

Vandebroek, I. and M. J. Balick. 2014. Lime for chest congestion, bitter orange for diabetes: Foods as medicines in the Dominican Community in New York City. Economic Botany 68(2):177-189. and - 2012. Globalization and loss of plant knowledge: challenging the paradigm. PLoS ONE 7(5):e37643.

- — - — - J. Yukes, L. Duran, F. Kronenberg, C. Wade, A. L. Ososki, L. Cushman, R. Lantingua, M. Mejia, and L. Robineau. 2007. Use of medicinal plants by Dominican immigrants in New York City for the treatment of common health conditions. Pages 39-63 in A. Pieroni and I. Vandebroek, eds., Traveling cultures and plants: The Ethnobiology and Ethnopharmacy of Human Migrations. Berghahn Publishers, New York.

Vandecandelaere, H. 2012. De schaduw van Matonge. Eric Verrept, Brussels.

Viladrich, A. 2007. Between bellyaches and lucky charms: Revealing Latinos' plant-healing knowledge and practices in New York City. Pages 6485 in A. Pieroni and I. Vandebroek, eds., Traveling cultures and plants: The Ethnobiology and Ethnopharmacy of Human Migrations. Berghahn Publishers, New York.

Walton, R. J., D. L. Whitten, and J. A. Hawrelak. 2016. The efficacy of Hibiscus sabdariffa (rosella) in essential hypertension: a systematic review of clinical trials. Australian Journal of Herbal Medicine 28(2):48-51. 